\title{
ソーダエ業その他の製造装置の防食管理 \\ The Corrosion Control of the Plants on the Soda \\ and Its Applied Industry
}

粟屋裕* 梶山裕 久*

Hiroshi Awaya and Yoshihisa Kajiyama

\section{1 緒言}

ベルギーのソルベーがアンモニア法ソーダ工業に着手 した当時，巨大なプラントを建設するのに，鋳鉄以外に 材料がなかったことは，ソルベーのために，ひいては近 代の化学工業のために，きわめて幸いであった。期せず して, ソルベーは 20 年, 30 年のすぐれた耐用材料を手 に入れたのである。そして, その成功は, 多くの化学工 業の発展につながっていった。

以来 100 年, アンモニア法ソーダ工業は, 部分的には 若干の改良がみられたが，塩化物溶液中で割れを生じな い鋳鉄は，十分に腐食しろさえとってやれば，これ以上

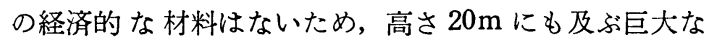
塔に至るまで，大半を鋳鉄に依存して，今日に至った。
こうして外観的には余り変化のみえないアンモニア法 ソーダ工業の材料に大きな問題を生じたのは, 肥料用, 工業用塩化アンモニウムの製造である。当社でも, 昭和 25 年, 肥料用塩化アンモニウムの製造によって, 始めて この激しい腐食問題に直面, 18-8 系ステンレス鋼を主と した防食研究に手がつけられるようになった。

また，当社では昭和 27 年，水銀法電解ソーダが発足 し, 生成する塩素を足がかりに石油化学に進出, ハーク ロルエチレン, 四塩化炭素のような有機溶媒から，才キ シクロリネーションによる塩化ビニルモノマーの合成 と高温に打ける塩素, 塩化物系を取り扱うようになり, このような新技術, 新プロセスの登場によって, 今まき にみられなかったところの新しい腐食形態がみられるト

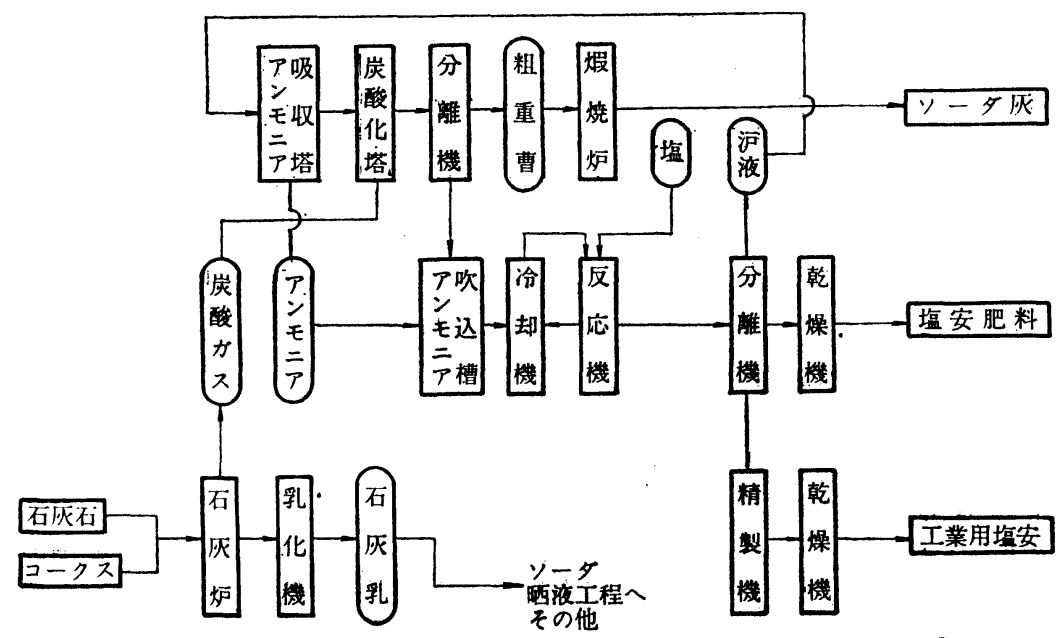

(1) ア法 (塩安ソータ法) 工程図

* 徳山曹達 (株) 研究部 (山口県徳山市御影町) Research Labora ory, Tokuyama Soda Co., Ltd. (Mikage-cho, Tokuyama-shi, Yamaguchi-ken, Japan)

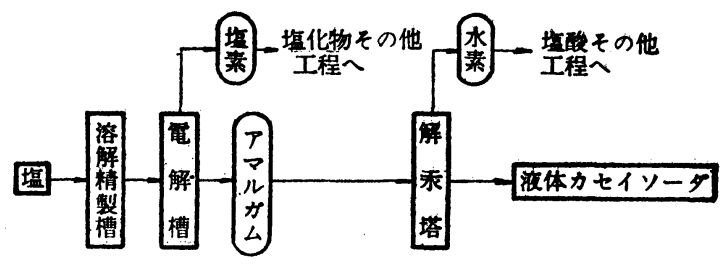

（2）水銀電解法工程図

図 1 ソーダ製造装置のフローシート 
表 1 防食管理組織と業務関連

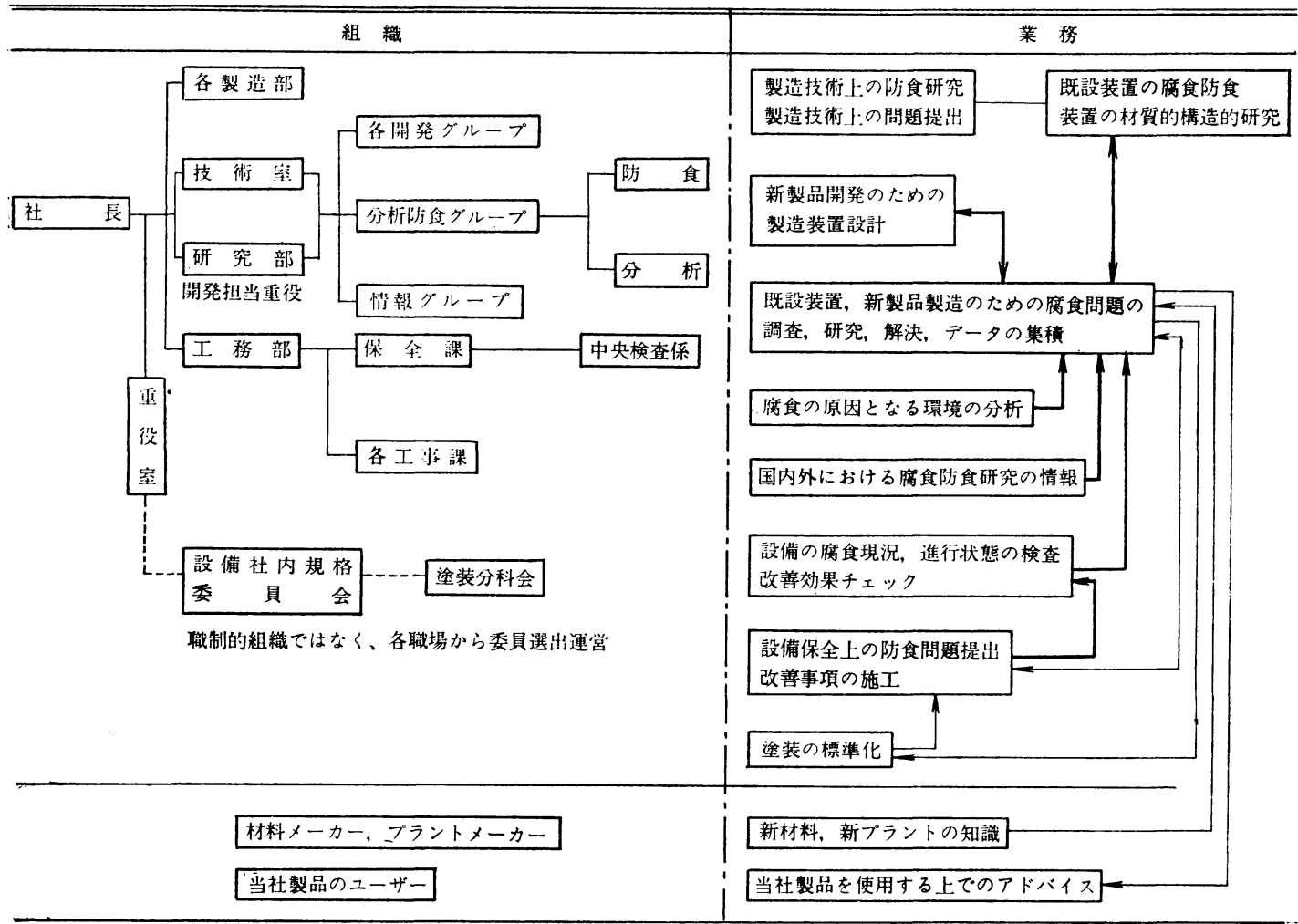

うになった。しかも，従来のアンモニア法ソーダ工業で は, 装置が腐食して使えなくなってから, 補修してもす む場所が少なくないのに対しこれらの新プロセスでは, アンモニア製造設備のように絶対事故を起こせない箇所 も次第にふえてきた。

また，最近製品の純度がだんだんと高品位が要求され るようになると，装置材料の腐食による製品の污染を避 计るため, 腐食しろさえとれば 40 年の使用も可能であ つた材料をやめて，腐食度のより小さい新材料を採用せ ざるを得なくなってきた。このように，新プロセスに限 らず，従来の装置プロセスについての検討を忘ることが たきない。

このような情勢のもとに，ソーダ工業および関連工業 において，いかに防食管理を行なっているか，当社を例 に述べてみたい。

\section{2 租}

防食の機構は, 化学工業各社それぞれの実体に合せて 作り，これを運営している。当社では䘚 1 のような体制 をとっている。

防食グループの業務活動を大別すると，実験室的な基 礎試験と現場試験と分けられるが，その対象は，1) 現 在ある製造装置の防食対策，2 2 新製品の研究開発のた
めの装置材料の選択である。当社では防食グルーブが技 術室, 研究部の両者の下におかれているのは，2）の目 的に最も対処しやすい体制だからである。

防食対策の上で, その環境の把握, 腐食生成物の組成 分析，さらに使用した装置材料がこちらで指定した通り の材質になっているかなどが問題になることが多い。こ うしたことから，一見まったく異質とみえる分析と防食 とに組織上つながりをもたせた。

また，当社が化学薬品を製造販売していることから， 自社工場の防食管理をするだけでなく，ユーザーのため にも，当社製品を使用する上でのアドバイスの役割りを もっていることも, 当社防食機構の一つの特徵てある。

\section{3 ソーダおよび関速工菜}

\section{$3 \cdot 1$ ア法ソーダおよびその誘迸品}

アンモニア法ソーダ製造のフローシートを図1（1)に 示した1)。

主な反応は次式のごとくである。

$$
\begin{aligned}
& \mathrm{NaCl}+\mathrm{NH}_{3}+\mathrm{H}_{2} \mathrm{O}+\mathrm{CO}_{2} \rightarrow \mathrm{NaHCO}_{3} \downarrow+\mathrm{NH}_{4} \mathrm{Cl} \\
& \text { 炭酸化 } \\
& 2 \mathrm{NaHCO}_{3} \rightarrow \mathrm{Na}_{2} \mathrm{CO}_{3}+\mathrm{CO}_{2}+\mathrm{H}_{2} \mathrm{O}
\end{aligned}
$$

层 焼.

（1）こ生じた $\mathrm{NH}_{4} \mathrm{Cl}$ 溶液の大半は $\mathrm{NH}_{3}$ を補給し，固 
型塩を加えて冷やすことにより，塩が溶解し， $\mathrm{NH}_{4} \mathrm{Cl}$ が 析出する。塩を加えた溶液は $\mathrm{NH}_{4} \mathrm{Cl}$ を分離後，（1）の 液に戻される。

$\mathrm{NH}_{4} \mathrm{Cl}$ の一部は

$$
\begin{aligned}
& 2 \mathrm{NH}_{4} \mathrm{Cl}+\mathrm{Ca}(\mathrm{OH})_{2} \rightarrow \mathrm{CaCl}_{2}+2 \mathrm{NH}_{3}+\mathrm{H}_{2} \mathrm{O} \\
& \text { (アンモニア蒸留) } \\
& \text { ここに用いる } \mathrm{Ca}(\mathrm{OH})_{2} \text { は } \\
& \mathrm{CaCO}_{3} \rightarrow \mathrm{CaO}+\mathrm{CO}_{2} \text {, } \\
& \mathrm{CaO}+\mathrm{H}_{2} \mathrm{O} \rightarrow \mathrm{Ca}(\mathrm{OH})_{2} \text { 石灰炉 }
\end{aligned}
$$

によって作られる。(3)の $\mathrm{NH}_{3}$ は（1）に戻される。ソ 一夕灰 $\left(\mathrm{Na}_{2} \mathrm{CO}_{3}\right)$ と塩安 $\left(\mathrm{NH}_{4} \mathrm{Cl}\right)$ を併産するため, ア ンモニア法という代りに塩安法とも言っている。誘導品 は (3) 式で生じる塩化カルシウムのほかに, ケイ酸ソ 一ダ, 無水ケイ酸, 塩基性炭酸マクネシウム, そして自 家消量のアンモニアが作られている。

アンモニア法ソーダ工業の大半は鋳鉄である ${ }^{2,3)}$ 。配 管類は遠心鋳造管を用いている。塩を飽和させたカン水 にアンモニアを吸収させた安カン水以後の溶液系に使用 する鋳鉄としては， $\mathrm{Al}$ 鋳鉄（Al 3\% 以上）がニレジス 卜，モネルよりも耐食的であるという提案がある゙)。

この系では, 鋳鉄は $0.2 \sim 0.5 \mathrm{~mm} / \mathrm{yr}$ 程度の腐食率て， 製品の污染を防ぐため，一部ステンレス鋼の装置が用い られている。これによって腐食率は $0.1 \mathrm{~mm} / \mathrm{yr}$ 以下に 抑えられるが, 塩化物溶液に特有の応力腐食割れ等の危 険性が生じている。

塩安製造の系では, SUS 27 程度のステンレス鋼は著 しく寿命が短かく， SUS 32 に代えるだけで著しく寿命 涎びることから，Mo の効果は著しいようである。し かし，実装置には，さらに高級なステンレス鋼が必要で ある。孔食, 間隙腐食, 応力腐食割れのおそれがある。

塩化カルシウムは（3）の液を濃縮して製造する。か つては鋳鉄釜で煮詰めていたが，蒸発缶を用いて，70\% 以上に濃縮するようになり，材料問題が重要になってき 心。

ケイ酸ソーダは, 次式をオートクレーブで行なう。

$$
2 \mathrm{NaOH}+n \mathrm{SiO}_{2} \rightarrow \mathrm{Na}_{2} \mathrm{O} \cdot n \mathrm{SiO}_{2}+\mathrm{H}_{2} \mathrm{O}
$$

製品は $\mathrm{Na}_{2} \mathrm{O} \cdot \boldsymbol{n} \mathrm{SiO}_{2} \cdot x \mathrm{H}_{2} \mathrm{O}$ の形である。

\section{$3 \cdot 2$ 水銀法電解ソーダおよびその誘導品}

水銀法電解は図 1 ( 2 (2) のごとくである。

不溶性電極十, 水銀一, 塩水を電解して, 塩酸とナト リウムアマルガムを作る。ナトリウムアマルガムは

$$
\mathrm{Hg}-\mathrm{Na}+\mathrm{H}_{2} \mathrm{O} \rightarrow \mathrm{NaOH}+\mathrm{H}_{2}+\mathrm{Hg}
$$

(解こう)

水銀法のカセイソーダは，普通 $48 \%$ の液体カセイに するが, 電流密度を上げれば, $70 \%$ 程度の濃度も可能で ある。しかし，この場合，解こうしたばかりの液は 140

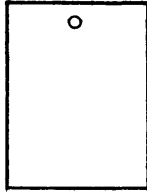

(1) 金面腐食用

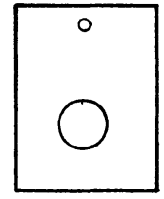

（2）応力腐食 割れ用

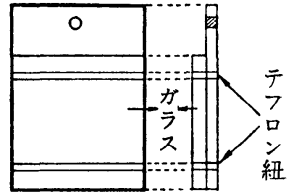

(3) 間隙腐食年
図 2 実験室浸漬用試験片

${ }^{\circ} \mathrm{C}$ 程度になり，装置材料を侵すおそれを生じる。

塩素の誘導品としては, 塩酸, さらし液, ホスゲン, 次亜塩䒺酸ソータの無機薬品のほかに，パークロロエチ レン, クロロホルム, 四壏化炭鴊の有機溶媒, 関連会社 で酸化プロピレン，二塩化エチレン，オキシクロリネー ション法による塩化ヒニルモノマー，ポリ塩化ヒニルが あげられる。

二塩化エチレンは, エチレンの塩素化で, $\mathrm{CH}_{2} \cdot \mathrm{CH}_{2}+\mathrm{Cl}_{2} \rightarrow \mathrm{Cl} \cdot \mathrm{CH}_{2} \cdot \mathrm{CH}_{2} \cdot \mathrm{Cl} \cdots(2)$

パークロルェチレン, 四塩化炭素などは, プロピレン の塩素化, または二塩化プロピレンの塩素化, 脱塩酸て 作られる。

塩化ビニルは，エチレンをオキシクロリネーションだ 二塩化エチレンにして

$$
\mathrm{C}_{2} \mathrm{H}_{4}+2 \mathrm{HCl}+1 / 2 \mathrm{O}_{2} \rightarrow \mathrm{C}_{2} \mathrm{H}_{4} \mathrm{Cl}_{2}+\mathrm{H}_{2} \mathrm{O} \cdots
$$

これを $450 \sim 550^{\circ} \mathrm{C}$ で熱分解して作る。

$$
\mathrm{C}_{2} \mathrm{H}_{4} \mathrm{Cl}_{2} \rightarrow \mathrm{H}_{2} \mathrm{C}=\mathrm{CHCl}+\mathrm{HCl}
$$

このように, 塩素化, 脱塩酸, あるいは塩化物の熱分 解等, 装置材料にとって, かなり㛜しい条件が課せられ ている。

\section{4 防食活助}

\section{$4 \cdot 1$ 材料の選択}

\section{$4 \cdot 1 \cdot 1$ 実験室試験}

ソーダおよび関連工業の特徵は塩素を含んでいること にある。このため, 腐食形態も全面腐食, 孔食, 間吵腐 食, 粒界割れ，粒内割れと種々多様である。

a ) 浸漬試験

浸漬用試験片も，全面腐食用のみでなく，各種の腐食 形態用のものも用いている（図 2 ）。

全面腐食用……...短冊形試片。孔食もこれで観察。

応力腐食割れ用 $\cdots$ 短冊形試片に約 $10 \mathrm{~mm} \phi$ の孔をあけ

て，応力を与えた。

間隙腐食用………短冊形試片の面にガラス板をあてて テフロンの組で締めつけた。

新規材料の場合，メーカー自身もその特徵を良く知ら ないため，全面腐食で良結果を得たからといって採用し て，失敗することがある。メーカーも経験の少ない新材 料のとき，特に気を配る必要がある。

b ）応力腐食割れ試験 


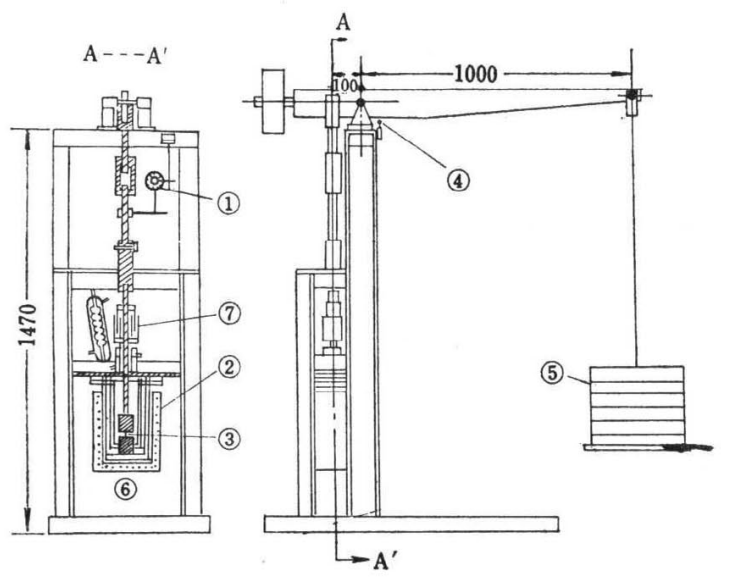

1：タイヤルゲーシ, 2:ヒーター, 3:試片，4：マイクロ スィッチ, 5 : 荷重, 6 : 腐食容器, $7:$ ウオーターシール

図 3 応力腐食割れ試験装置 (a) リング

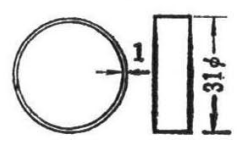

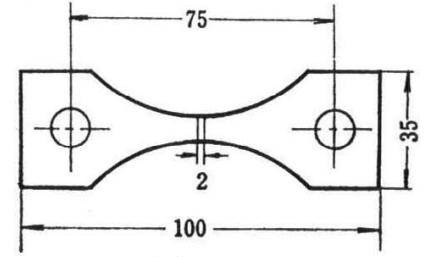

(b) プレート
図 4 応力腐食割れ用試片の形状と寸法

前節に述べたように, 塩化カルシウムを煮詀める過程 は, 蒸発缶を用いている。 $177^{\circ} \mathrm{C}, 72 \% \mathrm{CaCl}_{2}$ は非常に 苛酷な条件である。このため, 応力腐食割れに強い高二

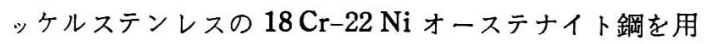
いたが，拡管部の応力腐食割れを防ぐことはできなかっ た。このため, 応力腐食割れを特に重視し, 図 3 のよう なテコ式の応力腐食試験機を試作した5)。

·試験片の形状は図 4 のごとくで, 試料がチューブのと きは輪切りにして, 溶接部が横にくるようにして, 押し つふしして扁平にし, 板状の試料は (b)のように切り出し た。

試験結果は, SUS 27 ては $20 \mathrm{~kg} / \mathrm{mm}^{2}$ て 20 分ももた ずに破断するが， $20 \mathrm{Cr}-30 \mathrm{Ni}-\mathrm{Mo}-\mathrm{Cu}$ ては $40 \mathrm{~kg} / \mathrm{mm}^{2}$ 以下の応力で実用上十分な耐性を示した（図 5 )。

蒸発缶においても，18Cr-20 Ni から $20 \mathrm{Cr}-30 \mathrm{Ni}, 22$ $\mathrm{Cr}-40 \mathrm{Ni}$ とチューブは次第に高級化したが, 早い時は 6 日, 長くても 40 日でチュブの割れによる運転停止を 余儀なくされた。

塩化カルシウムの場合, ニッケルをふやしても, オー ステナイト鋼であるかきり，応力腐食割れの危険を全く なくすことができないため，オーステナイト鋼以外に材 料を探すこととなった。

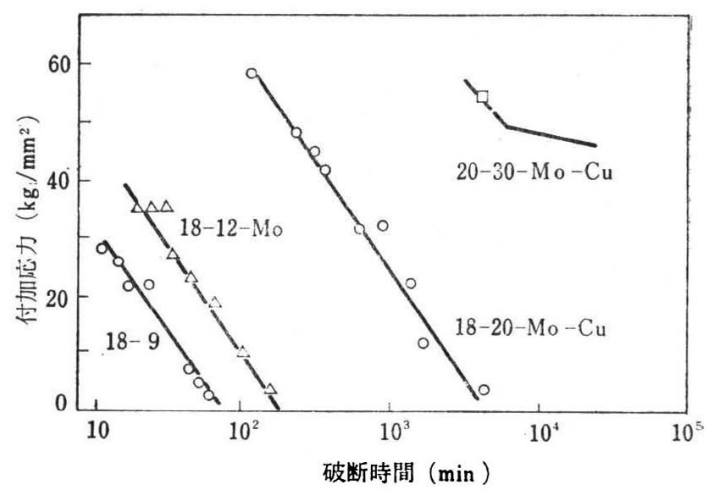

沸䏲 $60 \% \mathrm{CaCi}_{2}$ 溶液, リング状試料

図 5 塩化カルシウム溶液中のステンレス鋼の 応力腐食割れ

c）モデル化実験

実装置の腐食テストをするに当って，装置の中に試験 片を入れたからといって，この試験片の腐食から，装置 材料の腐食状態を把握できるとは限らない。熱交換器の ように，装置は内と外とで温度が異なっているかす知れ ないし, 腐食液の流速が器壁と試験片とて違うかも知れ ないからである。また試験片を実装置の中に入れること ができない場所もある。

こうしたとき，実装置の特徵をつかんで, 実験室試験 に再現する工夫をモデル化実験と命名した。伝熱面とく に熱交換器の腐食に, これを利用している。

d）その他

電気化学試験は主として定電圧電解装置（ポテンショ スタット)により, 電圧一電流密度曲線を求めるのは, 常法の通りであるが, 塩化物を含む系では, 孔食の特そ れが少なくないため, 孔食電位を電気化学的に求めるこ とに留意している。カセイソーダに対するステンレス鋼

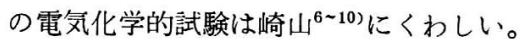

\section{$4 \cdot 1 \cdot 2$ 実地試 験}

a ) 事故調查とその対策

既設装置に事故を生じたとき，速やわに現地を調へ， 雲囲気, 腐食生成物, 使用材料の分析, 試料が切りだせ るときは, その顕微鏡組織の観察, 切りだせないときは, スンプによるレプリカ試料の作成をして，顕微鏡観察 し, 腐食形態の調査から, 腐食原因を解明し, その対策 をねる。

塩化アンモニウム関係では, $18 \mathrm{Cr}-20 \mathrm{Ni}-\mathrm{Mo}-\mathrm{Cu}$ と 指定して作らせたボルトが10日間程度て腐食したのて， ボルトを分析したところ, SUS 27 たっったいう納入材 料の誤りによる単純事故だったことがある。このため, SUS 27, 32，18 Cr-20 Ni-Mo-Cu 等，いくつかの標準 試料を用意し，ケイ光X線分析によって，直ちに使用試 料の組成が求められるようにしている。 

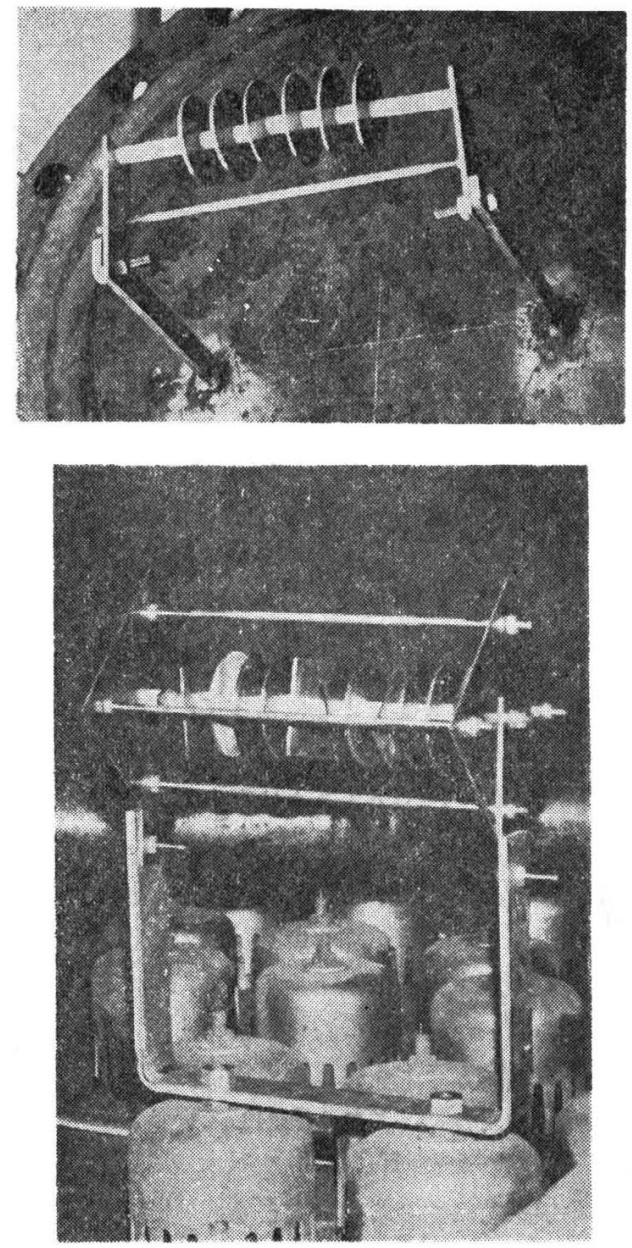

図 6 スプール枠の実装置の中への取り付けの一例

また，当社では応力腐食割れが多いので，チューブの 液洩れを例にとると，その割れが外側から入ったもの か，それと内側からか，さらに粒内割れか，鿓粒割れか 等の判断が重要な手がかりになることが多い。

事故の解析結果は，その時の対策に役立たせるだけて はなく, 事故の分析結果のデータを集積し, 再び同様の 会事故を生じたときの速やかな処理, 将来の装置改 良，新装置設計等に役立たしめている。

b) 漫漬試験

現場での漫漬試験はスプールテストを主としている。 全面腐食用と孔食用の測定は従来の円盤状の試験片を用 いるが、ソーダおよび関連工業では，応力腐食割れと間 隙腐食さ無視できない。このため，応力腐食割れ用とし ては，板状の試片をU字型に折り曲げることにより応力 索与え，間隙腐食用には 2 枚の同種試料はぴったり重ね 合せて，スプール枠にとりつけている。

スプール枠を実装置に取りつけた状態の実例は，図 6 に示した。
表 2 塩化カルシウム濃厚水溶液中の 各種金属材料の詹食試験

$\mathrm{CaCl}_{2} 72 \%, 177^{\circ} \mathrm{C}, 1$ 力月浸漬

\begin{tabular}{|c|c|c|c|}
\hline 材 & 料 & $\begin{array}{l}\text { 侵 食 度 } \\
(\mathrm{mm} / \mathrm{yr})\end{array}$ & 腐 食 形 態 \\
\hline \multicolumn{2}{|c|}{$\begin{array}{l}20 \mathrm{Cr}-30 \mathrm{Ni} \\
\text { (Carpenter } 20 \text { 相当品) }\end{array}$} & $0.15 \sim 0.20$ & $\begin{array}{l}\text { 全面孔食 } \\
\text { 応力腐食割狆もむり }\end{array}$ \\
\hline$=\%$ & ケ ル & $0.45 \sim 0.6$ & \multirow{2}{*}{$\begin{array}{l}\text { 全面腐食 } \\
\text { 全面腐食 }\end{array}$} \\
\hline モ & ネ & $0.65 \sim 0.8$ & \\
\hline イン & コネ ル & $0.20 \sim 0.25$ & \multirow{2}{*}{ 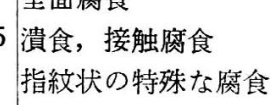 } \\
\hline チ & タ ン & 1.72 & \\
\hline \multicolumn{2}{|c|}{ チ (パラジウム入り } & 0 & 完全耐食 \\
\hline タン & タ ル & 0 & 完全耐食 \\
\hline
\end{tabular}

現場試験の例として, 塩化カルシウム濃厚溶液中方の 浸漬結果を，表 2 にかかげた。

$20 \mathrm{Cr}-30 \mathrm{Ni}$ ステンレス鋼でも，応力腐食割れは防げ ないが, ニッケルは全面腐食のみである。しかし, ニッ ケルはステンレス鋼よりも侵食がひどく，製品の污染か ら使用に耐えない。タンタルは完全耐食だが，経済的に なりたたない。当社ではニッケルより高級なある種の金 属を用い，これまで 1 力月連続運転もさずかしかった蒸 発出が，半年に 1 回の清掃で斉むという長期間運転を可 能にし，高級金属使用のメリットを得ることができた。

c) パイパスの設㯰

スプールテストは全工場について，系統的に行なって いる。しかし，実装置に試験片を入れる場合，休転にな るまで，試験片を取りだせないことが多い。もし，試験 片の中に腐食のはなはだしいものがあったら, 製品を污 染し，あるいはボロボロになった試験片のかけらによっ て，装置を損傷するといったトラブルを生じるおそれが ある。

このため, 当社では配管の腐食をテストする場合など， パイパスを作り，この中にスプール枠を設置している。 これにより任意の時に試験片を取りだせること，万一試 験片の腐食の激しいときは，そこのコックを締めるだけ て，運転に支障を来たさないようにでる利点がある。 ただしこのパイパスは工場建設時に設ける必要があ る。いったん操業が始まると，途中てバイパスを設ける ことは困難である。ただし，バイパスと本管とて，流速 が異なる点に考虑するべきである。

\section{2 渨境処理}

腐食対策には，材料面から攻める場合と，環境面から 攻める場合がある。環境面から行く場合には，運転条件 の変更と,インヒビターの添加とがある。

運転条件は，そう任意に変えられるものでない。一 方, 作る製品が食品工業の原料に使われるものでは, 食 

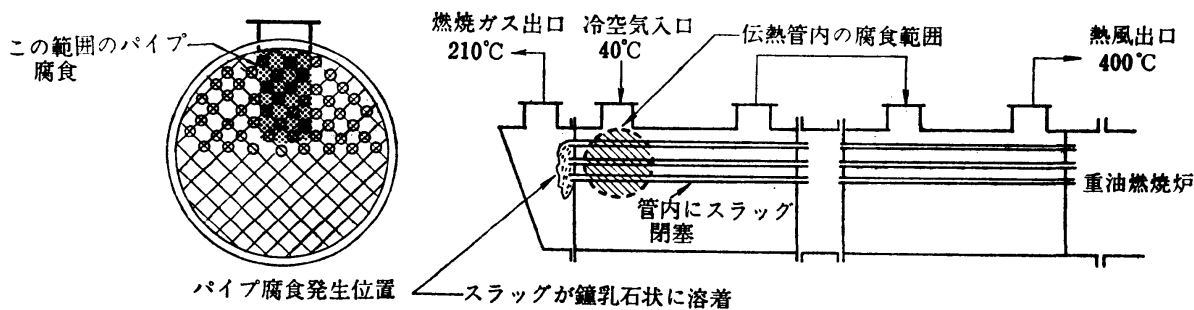

図 7 空気加熱器の低温腐食とその解決例（1）

空気加熱器の腐食発生状態

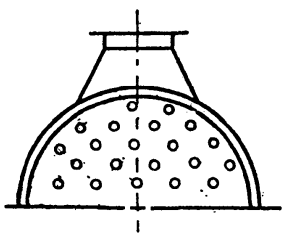

スロノズル改造図

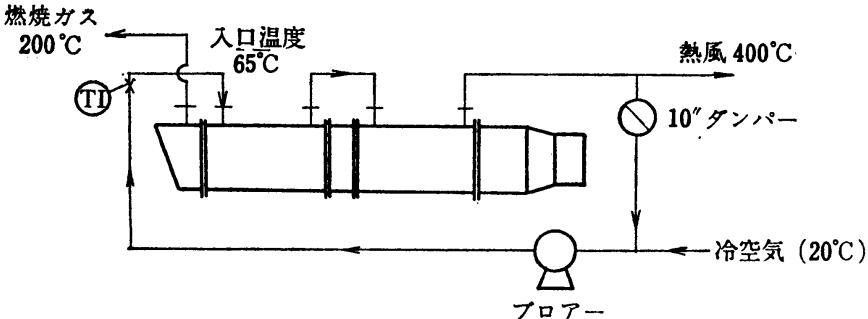

図 8 空気加熱器の低温腐食とその解決例 (2) 改造後のフローシート
品つ污染の䀣念から，インヒビターの使用が制限され $\vec{\partial}$

こうした制限の下に，もつとも大量にインヒビターを 用いているのは，冷却水に使われるブラインである。こ れは密閉系を循環して使用している。

インヒビターの研究は，その防食効果のほかに，製品 への污染のおそれ，インヒビターを含む廃水の処理法ま

厄，総合的に検討している。

当社における環境処理の例を次に示す。

アンモニア製造工程で, 重油を分解して $\mathrm{H}_{2}$ を作るが， この時発生する $\mathrm{CO}_{2}$ ガスをカリ液 (炭酸カリ) に吸収さ せ, $\mathrm{CO}_{2}$ と $\mathrm{H}_{2}$ を分離する工程がある。

$$
\mathrm{K}_{2} \mathrm{CO}_{3}+\mathrm{H}_{2} \mathrm{O}+\mathrm{CO}_{2} \rightarrow 2 \mathrm{KHCO}_{3}
$$

こうして生じた重炭酸カリ $\left(\mathrm{KHCO}_{3}\right)$ 溶液は $120 \sim 110$ ${ }^{\circ} \mathrm{C}$ 程度で加熱し, 上式の逆反応で $\mathrm{CO}_{2}$ ガスを吐出させ, 元のカリ液に戻して, 炭酸ガス吸収塔へ帰す。この逆反 応をさせる部分がリボイラである。

リボイラ内のチューブはU字型に曲げられ，重油分解 ガスが $200^{\circ} \mathrm{C}$ 以上の温度で入り，管内を通り，カリ液を $120^{\circ} \mathrm{C}$ に加熱し, 自らは $120^{\circ} \mathrm{C}$ 程度に下って, 缶外に出 万。

このU字管には SUS 33 を用いたが，最初サポータ一 との接触部に間吵腐食を起こし，次いて拡管部付近に割 れを生じた。このリボイラの腐食のため，しばしば運転 を中断し，アンモニア製造装置で一番のネックとなっ た。これは重油中にわずか含まれる塩素が，カリ液中に 溶け込むのが原因である。
これは,リボイラに入るガスの温度 (運転条件の変更) と，ある種のインヒビタ一の使用があいまって，さしも 激しかった腐食から開放され，連続運転の記録を伸ばせ るようになった。

\section{$4 \cdot 3$ 化学工学的な設骭}

材料面から，あるいは単なる環境処理では解決できず, 装置を改良しなくてはならない場合がある。

製品の乾燥のため, 空気を高温に加熱していた空気加 熱器の例をあげてみたい。

かっては石炭を燃焼させていた空気加熱器を, 重油専 焼に切りかえたとき，次のような事故を生した。

この空気加熱器は, 図 7 に示すように, 重油の燃焼力゙ スが管内を通り, 管の外側の空気を $400^{\circ} \mathrm{C}$ に加熱し, 自 らは $210^{\circ} \mathrm{C}$ となって系外に出るように設計された。硫酸 の露点による腐食は, $210^{\circ} \mathrm{C}$ て排気するので, 問題ない としたのである。

実際には，1 月月程度の運転て，スラッグが管の出口 を閉塞し, 冷空気の入口付近の伝熱管は, 典型的な硫酸 露点による腐食を受けていた。

そこて，詳細な伝熱計算を行なってみると，冷空気入 口付近の流速が大きいため, 伝熱管の表面温度が $100^{\circ} \mathrm{C}$ 以下になっていることが判明した。

この場合，鋼管を耐硫酸性のものに変えても，管の閉 塞に対しては無力である。対策としては, 硫酸の露点以 上に温度を上げる環境処理よりほかにない。問題は排気 の所で $210^{\circ} \mathrm{C}$ と計画しあっても， $40^{\circ} \mathrm{C}$ の冷空気の入口て の管内温度が露点以下に下っていることで, 冷空気はも 


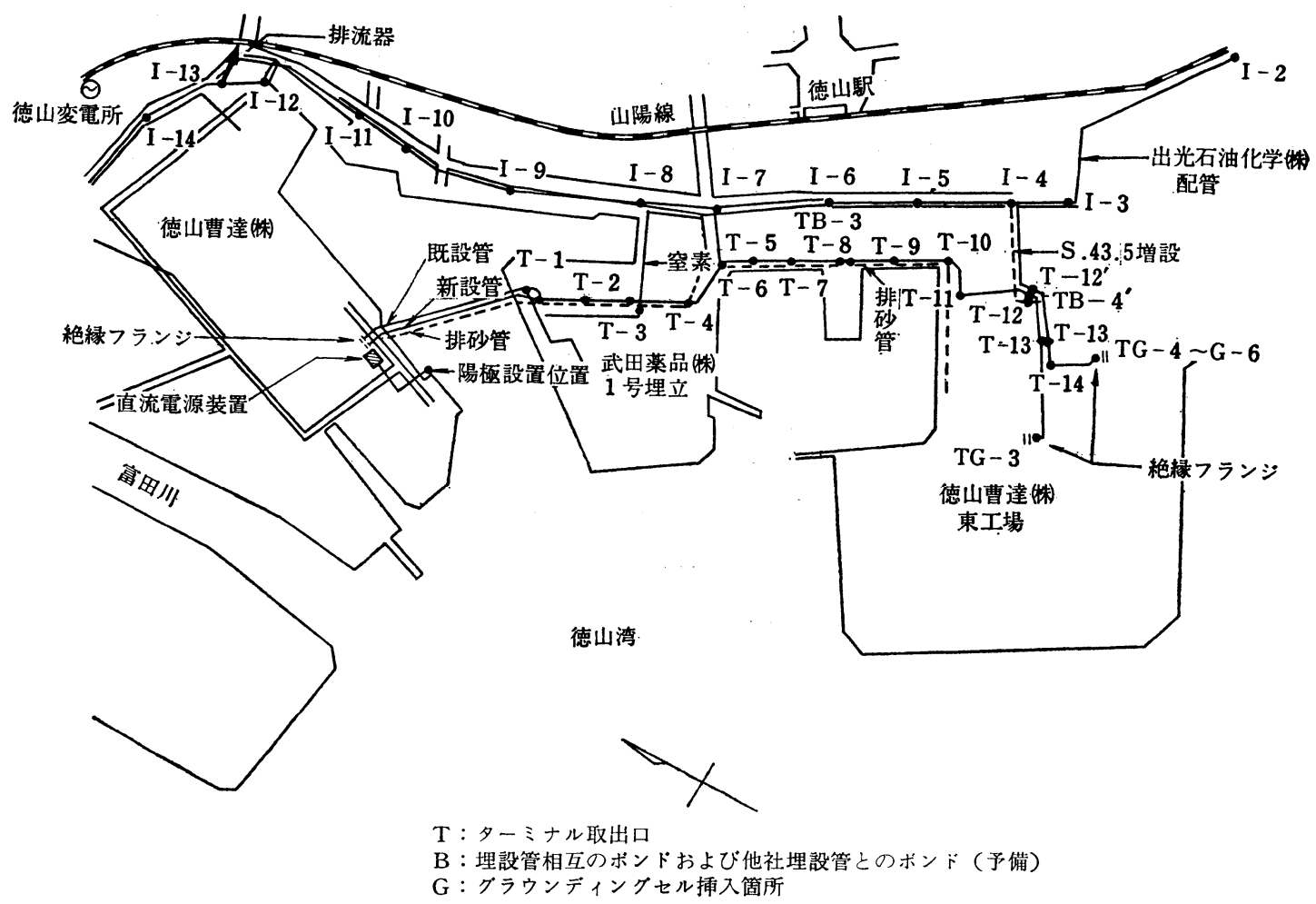

図 9 地下 埋 設 管

っと高い温度で入る必要がある。

ここに装置の改良が必要となった。計算の結果，第 1 に冷空気の入口ての速度を落すため, 加熱器への冷空気 の入口を広げ, 次いで, 冷空気は冬でも $60^{\circ} \mathrm{C}$ 以下に下ら ないようにするため，図 8 に示すように，400ㄷ の加熱 空気の 1 部を戻して, 冷空気と合流させ, 加熱器の入口 て $65^{\circ} \mathrm{C}$ になるように改造した。この簡単な改造で，こ の腐食はぴしゃりと治まった。

防食担当者は, ともすると材料面, あるいはインヒビ ターに限定して, 物を考えがちになりやすいが,このよ うに装置を改造しなくては, 解決できないことも多く, 化学工学的な面からの検討にも十分気を配る必要があ る。

\section{$4 \cdot 4$ 地下埋設管の設計, 工事, 保守}

当社では, ソーダ製造を主体とする徳山工場と, 塩素 を利用した一連の石油化学を主体とする東工場との間に 約 $2 \mathrm{~km}$ の原料輸送用の地下埋設管を敷いている。

この系については, 電気防食専門会社に依頼せず, 当 社独自で設計, 工事を行なった。

全長 $2,425 \mathrm{~m}$ (うち, 海底パイプ $255 \mathrm{~m}$ ) 図 9 に示すよ うに, 山陽本線および出光石油化学からのエチレン, プ ロピレン配管が平行して走り，これらの干涉のおそれが ある。海底管の徳山工場側で塩銀電極による外部電源法
による電気防食を行ない，陸上部は管対地電位の不安定 な部分にマグネシウム電極を取りつけたが，外部電源法 の電気防食の影響が東工場の末端まで及でいることが 確認された。

輸送する流体のうち，危険物の配管は二重管とし，内 管内を問題の流体が通るようにし，内管と外管の間は窒 素ガスを通し，随時，この窒素ガスを採取して分析し， 問題の成分の洩れがないことを確認している。

管対地電位の測定は春秋各 1 回定期的に行なうほか, 年 2 回程度不定期に検査している。

\section{4 -5 防食技術者の育成}

$4 \cdot 5 \cdot 1$ 新プロセス, 新工場への防食技術者の派遗 新プロセス, 新工場を建設した場合, ベンチスケール やパイロットプラントではみられなかった思いがけない 現象に見舞われることがある。

工場建設のさいには，それに先だって工事関係者と防 食担当者が念入りに打合せをして，最適材料を選ぶ努力 をしているが，スケールアップによって，多少環境条件 が変ることから, 万一腐食事故が起こったとしても, 直 ちにその状況に応じて，正しい措置がとれるようにする ため, 防食担当者も新工場について, その工程を熟知し ておく必要がある。

当社では, 新工場のできるとき, 運転員教育を徹底的 
に行なっているため, 新工場が建設された後, 運転が非 常にスムースに進められている。防食グループでは, こ の運転員教育に人を派遣し, 新工場について予侕知識を 得, また操業後, 直ちに現場でスプールテストがてきる ように, 試験する箇所, 材料等の検討を行なっている。

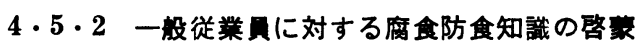

広大な工場の防食管理を数人の防食グループの手で行 なうことは不可能である。それぞれのプラントについて は，それを扱っている人が，その条件，状態につ心て一 番詳しいはずである。すなわち，それぞれのプラントの 防食を完全にするには，プラントをあずかる人自身，防 食について知識をもたねばならない。全社一丸となって の協力態勢ができて，始めて腐食防食の効果の実をあげ ることができるとの立場をとって，一般従業員に対する 防食知識の啓蒙に力を入れている。

\section{5 結}

当社の防食管理の実際をまとめてみると，

1) 長い間，鋳鉄に頼っていたア法ソーダ工業も，ソ ーダ灰の純度向上の必要から，一部ステンレス鋼を用い る等, 大幅な装置改良の問題を生じ，全社にわたり，ス プールテストを実施し，実地における腐食データを集積 した。従来のスプールテストでは全面腐食しか分らない ので, 間隙腐食用, 応力腐食割れ用のスプールテストを 工夫した。

2 ）腐食事故を調查し,速やかに対策をとると同時に, 事故分析結果のデータを集積し, 装置の改良, 新装置設 計に役立たしめた。

3 ) 実際の腐食を実験室的に再現するため，モデル化
実験，伝熱面の腐食試験等，特異な実験方法を考案した。

4 ）特に高温, 高濃度の塩化物の基礎実験を重点に実 施し, 新規の塩化物製品の工業化に役立たしめた。

5 ）海底管, 地下埋設管は, 特に危険物が多いのだ, 当社独自の電気防食設計を行なった。

6 ）全社一丸となって, 装置の防食に当たれるよう, 従業員に対し, 腐食防食知識の啓蒙に当っている。

以上の効果が十二分にあげられるよう，メーカーと接 触して新規材料, 新プラントの知識の吸取, 現場あるい は研究開発グループとの交流等に日夜努力を払ってい る。

\section{文献}

1) T.P. Hou: Manufacture of Soda, 2 nd Ed., Reinhold. N. Y., (1942).

2) G. Heinemann: Corrosion, 4, 516 (1948).

3 ）粟屋 裕, 吉松久三：化学工場, 10, No.7, 35 (1966).

4 ) 伊藤, 長野: 特許公告, 昭 31-3113.

5 ) 粟屋 裕, 吉松久三: 化学工学徳山大会講演 (1965).

6 ）崎山和孝, 藤本正美：東曹研報, 7, No. 1， 7 (1963).

7 ）崎山和孝, 藤本正美：東曹研報, 7, No. 2,42 (1963).

8 ) 崎山和孝, 藤本正美：東曹研報， 8, No. 1, 3 (1964).

9 ) 崎山和孝, 藤本正美：東曹研報, 8, No. 1, 6 (1964).

10）崎山和孝, 藤本正美：日本金属学会誌，30，617 (1966). 